INTERNATIONAL JOURNAL OF

MULTIDISCIPLINARY STUDIES ON MANAGEMENT, BUSINESS, AND ECONOMY

\title{
CERAMIC INCENSE BURNER AS ONE OF THE SYMBOLS OF THE SAUDI FOLKLORE AMONG THE ASSERTION OF THE ARAB IDENTITY AND FACING THE CHALLENGES OF THE LABOUR MARKET
} Samah Muhammad Abdel Nasser ABU ZAID *

Art Education Department, Faculty of Specific Education, Assiut University, Egypt

\begin{abstract}
The Saudi folklore, with all its elements, is a rich material of great importance in the formation of cultural, artistic and social characteristics in the Arabian Peninsula, and because it possesses expressive elements of a special character, the diversity of that expression in the Saudi cultural heritage. The research problem is determined in how to revive the Saudi folklore by developing innovative combinations of ceramic incense burners and the role of that in confirming the Arab identity and facing the challenges of the labour market.
\end{abstract}

Keywords

Ceramic, Incense Burner, The Saudi Folklore, The Assertion, The Arab Identity, The Labour Market.

\section{Introduction}

The design elements in folk art and in all types of plastic art are the vocabulary of the form language used by the popular artist, the modern artist, the potter, the designer, and even all plastic artists, and they are called design or formation elements in relation to their capabilities in taking any flexible body and their ability to merge, harmony and unite each other to form a form.

Entirely for the popular artistic work, but for the plastic artwork in general. Whatever those elements are - the artist's awareness in general and the popular artist in particular of her well-aware helps him in the planning process and makes his work easy and malleable, as well as helps him in evaluating his design and development, and thus helps him in activating his popular culture among all members of society through their taste for his artistic works in the field of art Plastic and folk art with its various branches, including porcelain.

Point, line and area are among the elements that the popular artist employed in his artwork (Ismail). The mass and some types of space are like the space between a mass of longing, three-dimensional three-dimensional elements that he employed in his artistic models. The researcher deals with the study in this research the plastic potentials of design elements in art and popular and Islamic decorative units and their use in developing innovative combinations of ceramic incense burners.

The ceramic incense burner is the one that members of the Saudi society deal with and use it in their daily life, and the tourist also brings with him some tourist souvenirs from those ceramic incense burners that express the Arab identity and carry with it the culture and civilization of the Saudi people, which leads to the activation of Saudi popular culture and its spread among global and local societies The research will deal with the concept of each of the design elements and the popular and Islamic decorative units and their role in enriching the surface of the ceramic incense burner and raising its plastic value, then the researcher analyzes it to find out its plastic capabilities and make use of those capabilities in creating innovative designs that carry aesthetic values in their folds and their interaction between modern societies to preserve Saudi folklore, whether those societies are local or global.

* Corresponding author: specedu@aun.edu.eg 


\section{Research Problem}

The problem of the current research is evident through the following questions:

1. How can the Saudi folklore be revived by developing innovative ceramic incense burners?

2. What is the role of the ceramic incense burner, as one of the symbols of the Saudi folklore, in confirming the Arab identity?

3. To what extent can cosmetic treatments of ceramic incense burners be found to meet the challenges of the labor market?

4. Are there modern implementation and fire methods in the field of ceramics that enrich the ceramic incense burner surfaces inspired by the Saudi folklore?

\section{Research Steps}

\section{A. The Theoretical Aspect}

1. The importance of popular and Islamic heritage in affirming the Arab identity.

2. Study and analysis of the plastic possibilities of the design elements of point, line, area, and color in Saudi folk art and motifs in Islamic art.

3. Shedding light on what is censer in the Saudi folklore.

4. Different types of fire in ceramic burner coating.

\section{B. The Application Side}

Conducting an experimental experiment in which:

1. Experimenting to employ the plastic capabilities contained in the Saudi folklore and Islamic motifs in creating innovative formations for ceramic incense burners by conducting an applied experiment on students of the Department of Art Education, College of Education, King Faisal University, fourth level.

2. Analyzing female students' work and identifying their aesthetic and plastic values.

3. Proposed work suitable as a production unit in the field of ceramics.

\section{Research Terms}

\section{General Definition of Heritage}

It is all that is present in us or with us from the past, whether it is our past or the past of others, whether near or far. "This definition is clearly a general definition that includes the intangible heritage of thought and behavior and the material heritage such as antiquities and others. The national heritage includes what is present in us from the past of the past It does not affect us as it links the heritage of the past to the present directly, so it is not only what belongs to the distant past, but it is also what belongs to the recent past and the recent past. It is connected to the present and the present. Its field is narrow as it is the point of connection of the past with the future. It is also a heritage, and the word heritage means in its linguistic origin what a man leaves to his heirs and a $\mathrm{T}$ in it instead of Waw, to reduce the pronunciation, and heir, heritage and inheritance are one, which is what he inherited.

\section{The Concept of Folklore}

It is all the symbols and forms that a person inherits, related to the creativity and culture of a people, and reveals very clearly the ethical and value system of society, as well as reveals his intellectual trends and perceptions of the universe and the nature of the relationship between the elements of the universe, and the ideas of the members of society, as well as intellectual and mental practices that attract children This community, meaning that the folklore represents the various aspects of the culture that the public adopts, with the existence of civilized cultures living side by side, with the possibility of an intellectual connection between each of them, and accordingly, 
scholars and researchers of folklore have been interested in codifying all the values, customs and legacies that are socially transmitted from Father to son and from neighbor to neighbor excluding mentally acquired knowledge, whether obtained through individual effort, or through organized and documented knowledge acquired within official institutions such as schools, institutes, universities, etc.

\section{Popular Art}

As a term that "describes handcrafted objects and decorations either for daily use or for decoration or for special occasions in life. Folk art is influenced by the group's patterns, culture, beliefs, and aesthetic perception of the environment, and this art arises among rural residents, deserts and popular classes within cities and folk art: it is related art. The thought and sentiment of a people and expresses its cultural identity, Its balance has accumulated across long cultures spanning the place and over time, and folk art is attributed to each The entire people is not attributed to a specific individual, and includes the inherited legacy and heritage, and the heritage is linked to a culture The word and the heritage of the artifacts passed down from generation to generation.

\section{Ceramic Incense Burner}

It is a performance by which incense and embers are placed to perfume the air surrounding the types of incense, and it is made of ceramic clay and burned to turn into pottery, then its surface is treated by various methods of painting and coloring the pottery to turn into a ceramic form.

\section{Porcelain}

It is everything that is formed from clay and is burned according to what was stated in the British Encyclopedia, then it is covered with a glaze that is known as "the result of a thermochemical process in which the surface of the ceramic body is covered with a well-adherent glass layer that works to block the pores and make the body easy to clean and gain smoothness and shine

\section{Identity}

The linguistic meaning of the term identity is derived from the pronoun it. The concept of identity refers to what is By him the thing is, that is, in terms of its personification, its realization in itself and its distinction from others, it is the vessel of conscience The plural of any human group, and the content of this conscience at the same time, including the values and customs it includes And the components of the adaptation of the group's awareness and will to exist and live within the scope of preserving its being. and in sum, the Arab and civilized identity of a nation is from the nations, Al-Jarari, Abbas, 1988 It is the constant, essential and common amount of common features and features that characterize this civilization The nation is distinguished from other civilizations, which give the national personality or national character a characteristic that distinguishes it from Other patriotic and national figures.

\section{Labour Market}

It is a theoretical hypothetical market and a type of economic market in which there are job seekers, business owners and others who create a workplace. And they are looking for labour.

\section{The Theoretical Side}

The word heritage in itself has more than one interpretation and meaning, and these interpretations and meanings differ accordingly For schools and specialists in the field of heritage, the word heritage includes the community's culture, customs, traditions, beliefs, and arts as well as inherited stories, tales and legends. The blogger and the popular oral. This: - Folklore is represented in a group of aspects:

1. Language, it contains many cultural and popular meanings. 
2. Folk literature, which is the aesthetic image of traditional culture

3. Music, arts, and dance that expresses customs and traditions.

4. Games, particularly games for children and youth, that are passed down through the generations.

5. Folk proverbs, stories and tales, customs and traditions on occasions and others.

6. Handicrafts and skills such as agriculture and handicrafts.

There are many aspects of heritage and its parts, which constitute the existential dimension of any society, and heritage represents the privacy of all societies, no matter how close they are to each other, and whatever similarities we find, but when we look closely at the heritage, we will find that this privacy represents the existentialism and identity of each society.

individually. In this research, the researcher will deal with the folklore, which is represented in the plastic arts aspect of folk arts, crafts, handicrafts and handicrafts, especially the field of ceramics.

The folklore is a great wealth of literature, values, customs, traditions, folk knowledge, material culture, plastic and musical arts, and it is a science that is now being studied in many foreign and Arab universities and institutes, so taking care of it is an urgent priority.

What is censer in Saudi folklore: -

The censer is one of the unique pieces of our Arab homes, and the Gulf in particular, as it has been associated for a long time Far away from perfuming clothes and homes, with the most beautiful perfumes. The censer was also associated with authentic customs such as welcoming the guest, showing affection and being warm with the best types of incense. Regardless of the functional importance of the incense burner, its mere presence adorns the Arab councils, in their many forms that have developed over the generations. There are many shapes between metallic, wood, glass and electrical that manufacturers have developed to match the colors of the majlis and its walls. While some are keen to acquire the traditional form of the incense burner, as a traditional and folklore that adorns the boards and exudes the most beautiful scents and perfume. And about the origin of the incense burner in the folklore, it is a vessel that was made in the past from local pottery, and its traditional shapes were of varying size. The owner of the house ignites the charcoal on fire and puts it in the pot, and then puts the sticks on it to be fumigated. Despite the development that was introduced to the original form of the incense burner, some of it are wooden and metal, and what works with electricity. However, its origin is made from local pottery

Therefore, the researcher was keen to treat the surface of the incense burner in the field of ceramics and pottery with different methods and various elements of the folklore, and there are different methods of burning the incense burner and painting it with glass paint in the use of an oxidizing fire type, and in the case of using reduced fire, a fire can be applied

Raku or House Ver.

The different types of fire in the ceramic burner coating: -

Reduction: It is the process of absorbing the oxygen in the metallic oxides that are added to the glass paint or painted on it, leaving the metal only, and it gives a kind of metallic luster that is colored in the color of the metal only. The carbon gas furnace, which performs a cycle, reduces the oxygen present in the metal oxide and leaves a trace of the metal on the surface of the ceramic object.

Oxidation: produced when the air increases during the settlement process and thus penetrates the gases and carbon and does not reduce Metal oxides in this case.

Raku: Raku is considered one of the most important techniques that the potters of the world learned from the 
heritage of Japanese ceramics, and raku from Japanese techniques in applying paint or lining, and it was started by the potter Chujiro in the year 1580 AD. The word raku means "pleasure or comfort." Raku ceramics are related to the tea drinking rituals of the adherents of the "Japanese Zen" religion, which is a religion that calls for contemplation and silence applied when drinking tea collectively. Raku ceramics are distinguished by imitating the forms of nature, especially rocks.

Porcelain House Ver:

\section{Results}

The firing pit, fire pit, or fire house is the oldest known method of clay firing. The pots are placed together in a hole in the ground and covered with inflammable materials such as logs, leaves, metal oxides, salts and sawdust. Then a fire is ignited inside the pit, after it is covered, until it is sure that the internal fuel has been completely consumed. After cooling, the pots are removed and cleaned to reveal the dramatic patterns and colors left over from the ash and salt.

\section{Discussing}

The researcher prepared an evaluation ruler for the ceramic artworks resulting from the practical experience Presented to cadres of faculty members and pioneers in art and art education, to measure the extent of inspiration from the elements of the Saudi and Islamic folklore to address the shape and surface of the ceramic incense burner, as well as the clarity of the Arab identity in it, and the following has been shown:

- The control group resulted in a group of traditional ceramic incense burners that do not express the Arab identity.

- As for the experimental group, it resulted in a variety of ceramic incense burners in terms of general shape and surface treatment of the incense burner, as well as the richness of the surface with elements of folk and Islamic heritage

1. The ceramic works, the result of the applied experience of the research, represented in the censer bear the features and characteristics of folklore and Islamic decorations, and confirm the Arab identity.

2. Female art education graduates were directed to set up small projects in the field of ceramic art to meet the challenges of the labor market.

3. Inspiration from the popular and Islamic heritage was a gateway to the tourist attraction in the Arab world

\section{References}

1. Ibn Manzur 1979 Lisan Al Arab, Dar Al Maaref, Cairo

2. Ismail Shawky 2000): Design, Elements and Foundations in Art, Cairo, Zahraa Al-Sharq.

3. AkramKanso: Arab Folk Photography, The World of Knowledge Series, Kuwait, 1999 AD.

4. 4. Al-Jarari, Abbas 1988): Components of Moroccan Cultural Identity, an article published in the book: The Cultural Identity of Morocco, The Book of Knowledge, The New Series.

5. 5. Mr. Muhammad Al-Sayed 1976 AD): The use of glass coatings from local raw materials and their application to some clays and the extent of their use in the field of education, $\mathrm{PhD}$ thesis (unpublished), Faculty of Art Education, Helwan University.

6. 6. JihanBayoumi Ahmad Aref (2003): Creating contemporary designs drawn from the Nubian heritage and making use of it in making ceramic murals, an unpublished master's thesis, Faculty of Art Education, Helwan University.

7. 7. Hanan Samir Abdel-Azim 2014): Contemporary Formulation of Arab Popular Symbols in the Field of 
Electronic Painting, Journal of Arts and Applied Sciences, Higher Institute of Applied Arts, Damietta University, Egypt

8. 8. Samah Mohamed Abdel Nasser 2013): Combining the different effects of glass coatings fire methods and making use of them in enriching the ceramic surface, unpublished $\mathrm{PhD}$ thesis, Faculty of Specific Education, Assiut University.

9. Muhammad Saad Shoman 2006 AD): Aesthetic values of modern raku ceramics, an unpublished master's thesis), Faculty of Applied Arts, Helwan University.

10. Tarabya, Mohieddin 1991): The importance of experimental activity in creating pictures and drawings, the Scientific Conference, Cairo.

11. Fatima Darwish 2010): Architecture and Folk Decorations in the Nuba and Asir Regions, katieb

12. The fifteenth conference of the University of Philadelphia, Jordan.

13. F0H0 Norton 1987): Ceramics by the Potter artist, translated by Said al-Sadr, Cairo. Arab Renaissance House, 2nd

14. Faisal Al-Omari 2012): Jordanian folklore and its representations in the work of students of plastic arts in the Faculties of Fine Arts in Jordan, a paper published in the Third International Forum for Plastic Arts (SouthSouth Dialogue) entitled Plastic Arts and Global Changes, Faculty of Specific Education, Assiut University, Egypt.

15. Qassem Abdo 1987): Popular Literature as a Tool to Know the Intellectual Life of the Peoples, Journal of Popular Arts, General Book Authority, 1999 AD.

Received: February 10, 2018

Accepted: April 23, 2018 